\title{
The long noncoding RNA Vax2os1 controls the cell cycle progression of photoreceptor progenitors in the mouse retina
}

\author{
NICOLA MEOLA, ${ }^{1,2}$ MARIATERESA PIZZO,${ }^{1}$ GIOVANNA ALFANO, ${ }^{1}$ ENRICO MARIA SURACE, ${ }^{1}$ \\ and SANDRO BANFI ${ }^{1,3,4}$ \\ ${ }^{1}$ Telethon Institute of Genetics and Medicine (TIGEM), 80131 Naples, Italy \\ ${ }^{2}$ The Open University, MK7 6BJ, Milton Keynes, United Kingdom \\ ${ }^{3}$ Medical Genetics, Department of General Pathology, Second University of Naples, 80138 Naples, Italy
}

\begin{abstract}
Long noncoding RNAs (IncRNAs) are emerging as regulators of many basic cellular pathways. Several IncRNAs are selectively expressed in the developing retina, although little is known about their functional role in this tissue. Vax2os1 is a retina-specific IncRNA whose expression is restricted to the mouse ventral retina. Here we demonstrate that spatiotemporal misexpression of Vax2os1 determines cell cycle alterations in photoreceptor progenitor cells. In particular, the overexpression of Vax2os1 in the developing early postnatal mouse retina causes an impaired cell cycle progression of photoreceptor progenitors toward their final committed fate and a consequent delay of their differentiation processes. At later developmental stages, this perturbation is accompanied by an increase of apoptotic events in the photoreceptor cell layer, in comparison with control retinas, without affecting the proper cell layering in the adult retina. Similar results are observed in mouse photoreceptor-derived $661 \mathrm{~W}$ cells in which Vax2os1 overexpression results in an impairment of the cell cycle progression rate and cell differentiation. Based on these results, we conclude that Vax2os1 is involved in the control of cell cycle progression of photoreceptor progenitor cells in the ventral retina. Therefore, we propose Vax2os1 as the first example of IncRNA that acts as a cell cycle regulator in the mammalian retina during development.
\end{abstract}

Keywords: Vax2os1; noncoding RNA; retina; photoreceptors; AAV

\section{INTRODUCTION}

Noncoding RNAs (ncRNAs) represent a significant portion of mammalian transcriptomes (Birney et al. 2007; Kapranov et al. 2007). In addition to "classic" housekeeping noncoding RNAs (e.g., ribosomal RNAs) and small noncoding RNAs (e.g., microRNAs) (Czech et al. 2008; Carthew and Sontheimer 2009), mammalian genomes encode numerous long noncoding RNAs (lncRNAs), which range from 200 bases to $100 \mathrm{~kb}$ in size (Carninci et al. 2008; Mattick 2009). Experimental evidence suggests that a large proportion of these lncRNAs are not the result of transcriptional noise (Ebisuya et al. 2008) but represent functional products (Ravasi et al. 2006; Amaral and Mattick 2008; Dinger et al. 2008; Pauli et al. 2011). However, lncRNAs tend to be weakly sequence-constrained, as compared with proteincoding genes, even though short stretches of sequence con-

\footnotetext{
${ }^{4}$ Corresponding author.

E-mail banfi@tigem.it.

Article published online ahead of print. Article and publication date are at http://www.rnajournal.org/cgi/doi/10.1261/rna.029454.111.
}

servation could nevertheless ensure the integrity of functional and structural domains (Pang et al. 2006).

In terms of genomic organization and their relationships with nearby transcripts, IncRNAs can be subdivided into two main categories, i.e., long intergenic noncoding RNAs (lincRNAs) and opposite strand (OS) noncoding RNA (OS-ncRNA) transcripts (Ponting et al. 2009). Until very recently, only a few examples of functional lincRNAs had been identified, notable among which is HOTAIR, a long intergenic transcript that recruits the Polycomb repressive complex (PRC2) to repress in trans transcription of genes localized at the HOXD locus and that is also involved in the regulation of cancer invasiveness (Rinn et al. 2007; Gupta et al. 2010). Recently, another trans-acting lincRNA, called HOTTIP, has been described activating the transcription of several HOXA genes in vivo by recruiting the proteins Mll1 and Wdr5 on the transcription start sites of the $5^{\prime}$ HOXA genes (Wang et al. 2011). Moreover, a large number of lincRNAs have recently been identified by a systematic approach based on chromatin-state maps in four mouse cell types. Many of these new lincRNAs have been found to be regulated by key transcription factor genes such as TP53, 
OCT4, and NANOG (Khalil et al. 2009; Huarte et al. 2010; Loewer et al. 2010). In addition, there are examples of lincRNAs involved in the establishment of chromatin states through the binding of chromatin-modifying proteins like the histone-methylases (PRC2 and G9a) and/or the histone-demethylases (CoREST, and SCMX) (Khalil et al. 2009; Tsai et al. 2010). Finally, lincRNAs are also emerging as important regulatory molecules in tumor-suppressor and oncogenic pathways (Huarte and Rinn 2010). On the other hand, OS-ncRNAs are organized as cis-natural antisense transcripts, i.e., transcripts that overlap one or more of the exons or the promoter of an independent transcript, usually protein-coding (Lapidot and Pilpel 2006; Ponjavic and Ponting 2007), which is located on the complementary DNA strand. OS-ncRNAs have been found in a few cases to regulate the expression of their cognate genes through a variety of mechanisms, i.e., via the formation of doublestranded RNAs, transcriptional interference, activation/inactivation of transcription, DNA methylation, and histone modifications (Mercer et al. 2009; Werner et al. 2009), in which case they may also be termed "natural antisense transcripts." In general, however, the function of most lncRNAs identified to date remains elusive.

Previous work has shown that many lncRNAs are selectively expressed in the developing central nervous system (CNS) (Mercer et al. 2008). Interestingly, several lncRNAs are expressed in the retina, a specialized part of the CNS, but their role has not yet been elucidated. Recently, we and others have identified, and begun to characterize, a subset of lncRNAs, more specifically OS-ncRNAs, associated with transcription factors that are known to play a basic role in retinal development in vertebrates (Alfano et al. 2005; Rapicavoli and Blackshaw 2009). Among the latter, Vax2os represents a very intriguing case. It is an OS-ncRNA in relation with the $\operatorname{Vax} 2$ transcription factor gene (Barbieri et al. 2002), in "head-to-head" orientation. Both Vax2 and Vax2os display a polarized expression in the eye with a highventral to low-dorsal expression gradient (Barbieri et al. 1999; Corbo et al. 2007). Here, we have found that the spatiotemporal misexpression of Vax2os 1 in vivo determines a perturbation of cell cycle progression in the progenitors of the most specialized retinal cells, i.e., photoreceptors. Moreover, this effect is not associated with changes in the expression levels of the neighboring gene Vax2. To the best of our knowledge, Vax2os1 represents the first example of a retinal lncRNA involved in the modulation of cell cycle progression during retinal development.

\section{RESULTS}

\section{Vax2os genomic organization and expression analysis}

Vax2os was reported to display a retina-specific expression both during embryonic and postnatal development (Alfano et al. 2005; Corbo et al. 2007) and presents five isoforms generated by alternative splicing (Supplemental Fig. 1A). The entire Vax2os locus spans $\sim 19 \mathrm{~kb}$ on mouse genomic DNA and contains a sequence domain, of $\sim 130$ bases, localized within the Vax2os1 isoform, which is highly conserved across all mammalian genomes, including the rat, human, and other primates (Supplemental Fig. 1A). This fragment represents the longest sequence conservation signature within the whole Vax2os transcriptional unit. A detailed in silico analysis of the latter conserved sequence, mostly carried out by using the ENCODE data set (Birney et al. 2007), did not yield any striking result apart from the presence in some tissues of a putative $\mathrm{H} 3 \mathrm{~K} 4 \mathrm{mel}$ modification site and of a P300 putative binding site, which are known to characterize sequence elements endowed with enhancer function (Ong and Corces 2011; data not shown).

We first performed an analysis of the temporal expression profile of all the Vax2os isoforms in the mouse retina by quantitative Reverse Transcriptase-PCR (qRT-PCR) analysis. We found that the Vax2os1 isoform displayed the highest expression levels across all stages analyzed. Among the other isoforms, Vax2os3, Vax2os4, and Vax2os5 displayed lower but yet noticeable expression levels, whereas Vax2os2 was barely detected at the stages analyzed. In particular, we found that Vax2os 1 expression in the retina was more evident during embryonic development than in postnatal stages (Supplemental Fig. 1B).

Previous RNA in situ hybridization (ISH) studies determined that Vax2os is expressed in adult photoreceptor cells, presumably rod photoreceptors, with a ventral (high) to dorsal (low) expression gradient in the eye (Corbo et al. 2007). We performed a more comprehensive RNA ISH analysis of the expression profile of the most relevant Vax2os isoforms during all the main stages of retina development, during both embryonic and postnatal stages. We selected the Vax2os1 and Vax2os5 transcripts that showed the highest expression levels by qRT-PCR and were the most representative of all the different isoforms (Supplemental Fig. 1B). We detected a reliable signal for the Vax2os1 isoform, while the Vax2os5 could not be detected at any stage analyzed, suggesting that its expression levels may be below the threshold of detection by RNA ISH procedures. We observed that Vax2os1 expression was limited to the ventral part of the retina at all the embryonic stages analyzed (i.e., embryonic day 10.5 [E10.5], E12.5, E14.5, and E16.5) (Fig. 1A-C; data not shown). Of note, this expression domain was prevalent in the outer neuroblastic layer (oNBL) of the developing retina at E12.5 and E14.5 (Fig. 1A,B). At these stages, the oNBL contains most of the retinal cells that are still proliferating, including the rod photoreceptor progenitor cells. At E16.5, Vax2os1 expression was also prevalent in the oNBL but was also detected in some cells of the inner neuroblastic layer (iNBL). We did not observe any Vax2os1 expression at the early postnatal stages of retina development, namely, PN1, PN4, and PN8 (Fig. 1D-F). Conversely, Vax2os1 expression was 


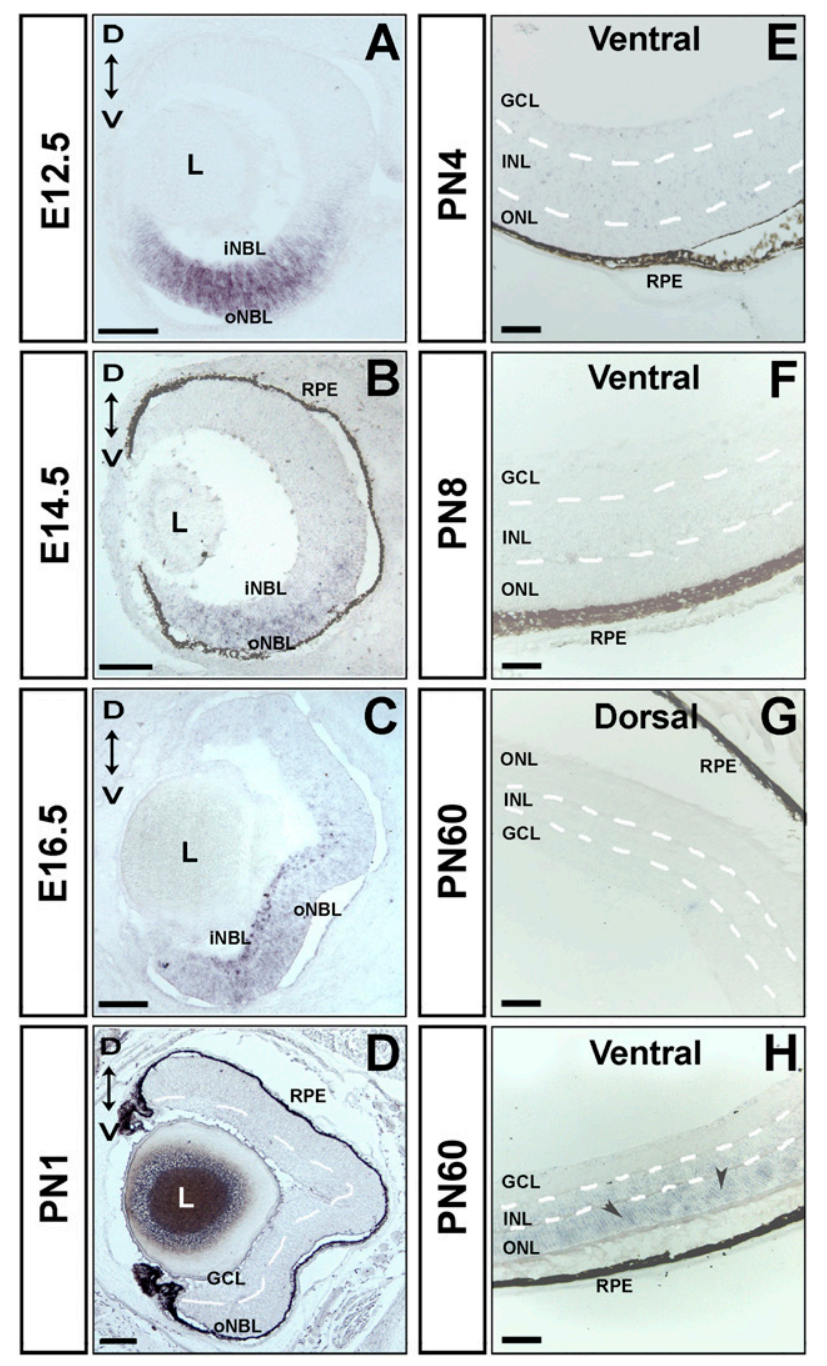

FIGURE 1. Vax2os1 expression pattern in the embryonic and postnatal mouse retina by RNA in situ hybridization (ISH). $(A-C)$ Vax2os1 is expressed in the ventral areas of the mouse embryonic retina from stages E12.5-E16.5. (D-F) In the postnatal stages, Vax2os1 is not detected by RNA ISH, while in the adult retina, Vax2os1 is expressed only in the outer nuclear layer of the ventral retina (arrowheads) $(G, H)$. All pictures derive from C57/Bl6 mouse retinas except for $A$ and $C$, in which albino CD1 mice were used. (oNBL) Outer neuroblastic retina; (iNBL) inner neuroblastic retina; (GCL) ganglion cell layer; (RPE) retinal pigment epithelium; (L) lens; (ONL) outer nuclear layer; (INL) inner nuclear layer; (D) dorsal; (V) ventral. Note that the borders of the retinal cell layers of postnatal and adult retinas are marked by dotted lines. Magnifying bars, $100 \mu \mathrm{m}(A-D)$; $40 \mu \mathrm{m}(E-H)$.

detected in the ventral region of the mature retina (PN60); the signal was restricted to the outer nuclear layer (ONL), where the nuclei of photoreceptor cells reside (Fig. 1G,H), in agreement with previous data (Corbo et al. 2007). The Vax2os1 expression gradient along the dorsal-ventral axis of the retina is reminiscent of the ocular expression domain of the Vax2 transcription factor (Barbieri et al. 1999). However, unlike Vax2os1, Vax2 expression is enriched in the inner neuroblastic layer during the embryonic stages and in the ganglion cell layer (GCL) and inner nuclear layer (INL) in the mature retina (Barbieri et al. 1999, 2002; Ohsaki et al. 1999).

The above results indicated that Vax2os 1 is the isoform that displays the most significant expression levels during retinal development. Considering also the presence of a conserved sequence domain within its sequence (Supplemental Fig. 1A), we hypothesized that the Vax2os1 isoform is more likely than the other isoforms to exert a functional role. Therefore, toward the goal of performing a functional characterization of the Vax2os lncRNA, we focused our efforts on the Vax2os 1 isoform, as detailed below.

\section{Analysis of Vax2os1 expression in retinal cell lines and identification of a putative VAX2OS human homolog}

Taking into account the expression of Vax2os1 in the proliferating retinal cells and in the mature photoreceptor cells, we decided to use mouse 661W (Al-Ubaidi et al. 1992) and human Y79 cells (Reid et al. 1974), two photoreceptor-like cell lines, as in vitro systems to gain initial insight into the putative role of this transcript. First, we treated $661 \mathrm{~W}$ cells for $48 \mathrm{~h}$ with a medium supplemented with sodium butyrate, taurine, heparin, and basic Fibroblast Growth Factor (or FGF2) in order to induce cell cycle exit and to promote a further differentiation of cells toward photoreceptors, as previously described (Comitato et al. 2007). We confirmed the validity of this protocol by both assessing the increase in the expression levels of photoreceptor marker genes and by morphological analysis of the cells after treatment (Supplemental Fig. 2A-E; data not shown). Under these conditions of differentiation, Vax2os1 was significantly up-regulated (Supplemental Fig. 2F). Interestingly, we obtained similar results in the human retinoblastoma Y79 cell line when we tested a putative human VAX2OS homologous sequence, corresponding to the above described evolutionarily conserved sequence element. In particular, we observed a striking up-regulation of the human VAX2OS in the Y79 cells treated with sodium butyrate to enhance their differentiation toward a photoreceptor-like fate (Supplemental Fig. 3A-C; Peng and Chen 2007). The efficacy of the latter differentiating protocol was confirmed by the expected down-regulation in the expression of early markers of photoreceptor cells, e.g., Crx, and by the concomitant up-regulation of genes expressed in differentiated photoreceptors, i.e., Rhodopsin (Supplemental Fig. 3A-C), as also previously described (Boatright et al. 2002; Peng and Chen 2007). The above results are not only in agreement with the significant expression of Vax2os 1 in the mature photoreceptor cell layer (Fig. 1) but strongly suggest the conservation of a functional VAX2OS transcript also in the human genome. 


\section{Vax2os1 overexpression impairs the cell cycle progression of differentiating $661 \mathrm{~W}$ cells}

We designed both loss-of-function and gain-of-function approaches to perform a study of the function of Vax2os 1 using the $661 \mathrm{~W}$ in vitro system. However, all attempts to down-regulate Vax2os1 by RNA interference (RNAi) technology failed to yield acceptable levels of Vax2os1 repression (four different oligonucleotides were tested) (data not shown). We then decided to focus on gain-of-function studies by overexpressing Vax2os 1 in $661 \mathrm{~W}$ cells. To this purpose, we transiently transfected cells with Vax2os1 and applied the differentiation protocol for $48 \mathrm{~h}(24 \mathrm{~h}$ after transfection) (Supplemental Fig. 4A). More in detail, we generated a plasmid vector carrying a bidirectional transcriptional cassette that expresses both Vax2os1 and the Green Fluorescent Protein (GFP) reporter gene under the control of the CMV (cytomegalovirus) and CBA (CMV early enhancer/chicken $\beta$-actin) promoters, respectively (Supplemental Fig. 4B). As controls, we used (1) two similar constructs carrying mutated forms of the Vax2os 1 transcript, namely, one with an internal deletion that includes the above described conserved sequence domain (delOS1) and one including a region at the $3^{\prime}$ end of the transcript (del2OS1); and (2) a construct that expressed only the GFP reporter under the control of the CBA promoter (Supplemental Fig. 4B).

We did not detect any apparent change in cell morphology in the 661W cells that overexpressed Vax2os1 (OS1$\mathrm{OE})$ compared with the cells transfected with either the GFP reporter only (GFP-OE) or the delOS1 construct (delOS1-OE) or the del2OS1 construct (del2OS1-OE). However, we observed a significant perturbation in the cell cycle rate of the OS1-OE cells after $48 \mathrm{~h}$ of differentiation, compared with either the GFP-OE- or delOS1-OE-transfected cells. This was assessed by evaluating the ratio between cells positive to either the cell proliferation marker Ki67 or the mitotic marker phospho-Histone-H3 (pHH3) versus the total pool of GFP-positive cells (Fig. 2A-D). No significant differences were observed when comparing OS1$\mathrm{OE}$ with del2OS1-OE-transfected cells (data not shown).

To obtain more precise information on the cell cycle progression of the OS1-OE cells and to analyze in detail each phase of the cell cycle, we carried out propidium iodide (PI) staining experiments. In particular, GFP-labeled OS1-OE cells, control GFP-OE, and delOS1-OE cell pools were sorted by Fluorescence Activated Cell Sorting (FACS) methodology following PI staining. This analysis revealed an increased number of OS1-OE 661W cells in the $S$ and $\mathrm{G}_{2} / \mathrm{M}$ phases after $48 \mathrm{~h}$ of differentiation compared with the GFP-OE and delOS1-OE control cells (Fig. 2E,F), which suggests that Vax2os1 overexpression determines an alteration of the cell cycle rate in $661 \mathrm{~W}$ cells.

We studied the localization and the expression levels of differentiation markers in the OS1-OE cells and control cells to detect possible alterations in cells following Vax2os1 overexpression. To achieve this aim, we carried out immunofluorescence stainings with an antibody against Tuj-1, which is a marker for differentiated neuronal cells. The staining revealed fewer OS1-OE cells positive to Tuj-1 compared with the control cells (GFP-OE) (Supplemental Fig. 5A). Furthermore, the expression of Rhodopsin, a rod photoreceptor-specific marker, was significantly down-regulated in the OS1-OE cells compared with the control cells (Supplemental Fig. 5B). We did not observe any perturbation after Vax2os1 overexpression in the 661W cells that did not undergo the differentiation protocol (Supplemental Fig. 5C; data not shown). Overall, these in vitro data suggest that high levels of Vax2os1 during cell differentiation lead to a perturbation of cell cycle progression in $661 \mathrm{~W}$ cells.

\section{In vivo misexpression of Vax2os1 affects retinal progenitor cell proliferation}

To determine the role of Vax2os1 in vivo, we used AdenoAssociated Virus (AAV)-mediated gene delivery (Allocca et al. 2007). Due to the previously mentioned difficulty in obtaining an efficient down-regulation of Vax2os1 by RNAi, we focused on Vax2os1 overexpression also in vivo. We decided to carry out these experiments by injecting AAV constructs (see below) in the dorsal retinal areas of postnatal day 1 (PN1) mice to perform a misexpression of Vax2os1 at both spatial and temporal levels. Indeed, Vax2os1 is not only prevalently expressed in the ventral retina but, at PN1, this transcript is expressed at very low levels across the entire retina (Fig. 1; Supplemental Fig. 1B). For this study, we took advantage of the same DNA plasmids that were generated for the in vitro studies (Supplemental Fig. 4B), for the production of AAV constructs that express Vax2os1 and GFP (AAV-OS1), the deleted form of Vax2os1, and GFP (AAV-delOS1) and GFP only (AAV-GFP). For each injection experiment, we used the following strategy: The AAV-OS1 construct was injected subretinally in the right eye of a cohort of $\mathrm{C} 57 \mathrm{Bl} / 6$ mice, whereas the contralateral eye was independently injected with either of the two control constructs. At least four mice, from a minimum of two independent injections, were analyzed in each experiment.

To evaluate the efficiency of AAV transduction, we performed qRT-PCR at PN5, i.e., $4 \mathrm{~d}$ after injection, and we detected a significant increase of Vax2os 1 expression in the AAV-OS1-injected retinal areas with a fold increase ranging between 2.5 and 16 compared with the AAV-GFPinjected eyes (Supplemental Fig. 6). We were able to detect GFP expression in the RPE of injected retinal areas (data not shown), in agreement with the results previously reported for AAV-mediated subretinal delivery at early postnatal stages (Surace et al. 2003; Colella and Auricchio 2010). 


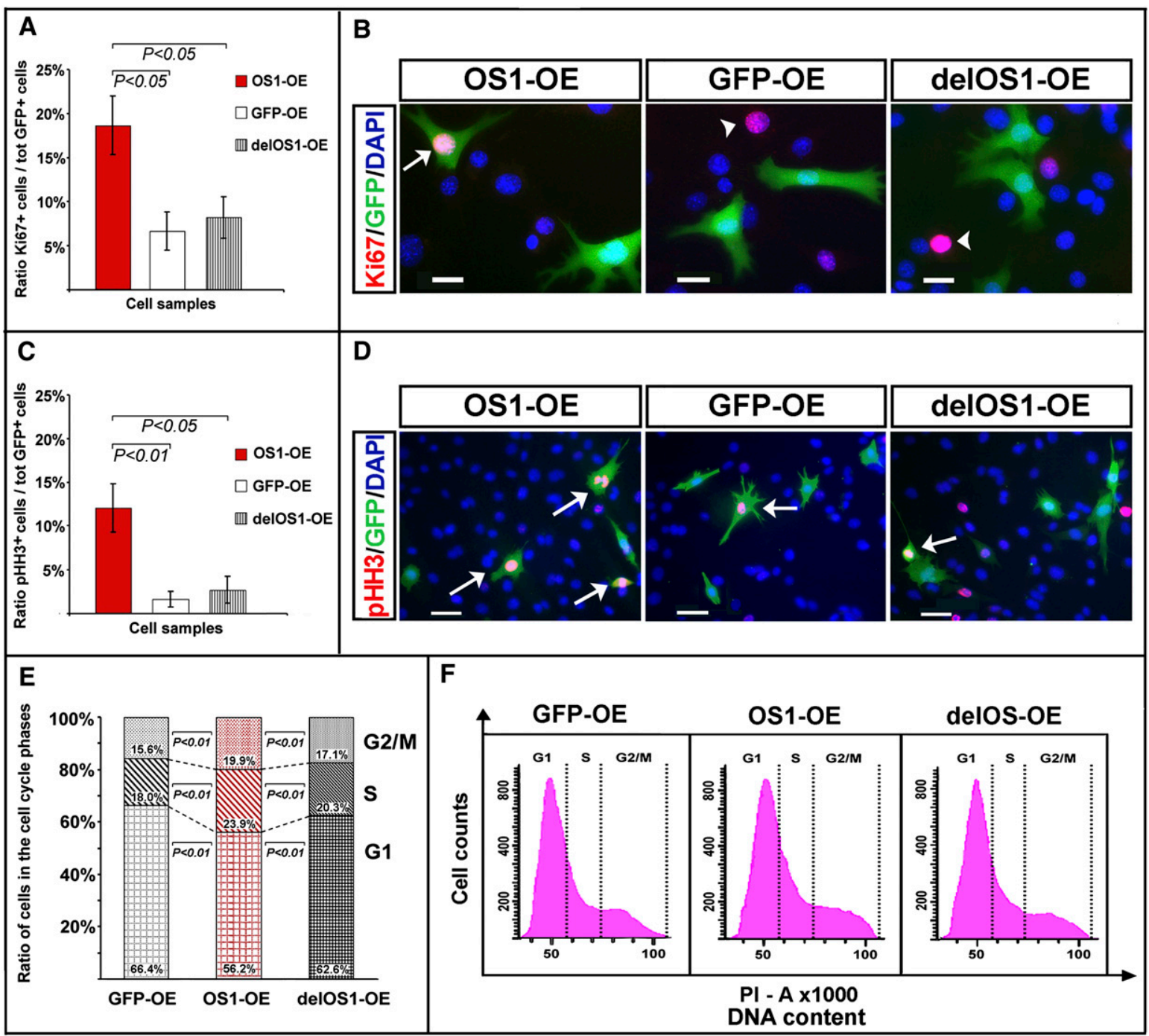

FIGURE 2. Vax2os 1 overexpression impairs the cell cycle of $661 \mathrm{~W}$ cells. Characterization of the $661 \mathrm{~W}$ cells undergoing a differentiation protocol for $48 \mathrm{~h}$ (see text for details). ( $A, B)$ Ki67 fluorescence immunostaining. ( $C, D)$ Phospho-histone-H3, pHH3, fluorescence immunostaining. In $A$ and $C$, the histograms show that the Vax2os1-transfected cells (OS1-OE) are characterized by an increase in the number of cells positive to Ki67 (A) or pHH3 (C) compared with the pool of control transfected cells (GFP-OE and delOS1-OE; see text for details). In B, the arrow indicates one Vax2os1transfected cell expressing Ki67; arrowheads indicate cells expressing only Ki67 in control experiments. In $D$, arrows indicate cells expressing both pHH3 and GFP in either the OS1-OE or the GFP-OE and delOS1-OE cells. (E,F) Cell cycle analysis with propidium iodide (PI). (E) Histograms show the distribution (in percentage) of the single cycle phases for the OS1-OE cells (middle bar) in comparison with the GFP-OE (left bar) and delOS1-OE control (right bar) cell pools. Differences between the GFP-OE and delOS1-OE were not significant. (F) Flow cytometric DNA content analysis of the OS1-OE cells and GFP-OE and delOS1-OE control cells stained with PI. $(A, C)$ Statistical $P$-values from likelihood ratio test for the negative binomial; $(E)$ statistical $P$-value from $\chi^{2}$ test. Magnifying bars, $20 \mu \mathrm{m}(B) ; 40 \mu \mathrm{m}(D)$. $(A, C)$ Data are represented as means \pm SEM, $n=4$.

The animals injected at PN1 were then analyzed at different time points, i.e., PN6, PN12, and PN30. At PN6, the analysis of the AAV-OS1-injected retinas revealed an increased number of proliferating cells, particularly in the prospective outer nuclear layer (ONL) as assessed by both Ki67 and pHH3 staining compared with both the AAVdelOS1- and AAV-GFP-injected retinas (control-injected retinas) (Fig. 3A-F,J,K). Interestingly, this finding was restricted to the dorsal retinal areas, i.e., where the AAV constructs were injected, and only to the ONL (Supplemental Fig. 7A-D). We did not observe any difference in the Ki67- and pHH3-positive cells between the AAV-OS1and control-injected retinas in the inner nuclear layer, INL (data not shown). Ki67 is a marker of the entire cell cycle and stains all the cycling cells, while $\mathrm{pHH} 3$ stains only the late $G_{2}$ and mitotic cells. To confirm the above data, we also performed a $\mathrm{BrdU}$ (5'-bromo-2'-deoxyuridine) incorporation assay in injected eyes (24-h pulses). At PN6, we found an increase of BrdU-positive cells in the prospective outer nuclear layer (ONL) of the dorsal AAV-OS1-injected retinas versus the control-injected retinal areas (Fig. 3G$\mathrm{I}, \mathrm{L})$. This finding was not observed in the ventral retinal 


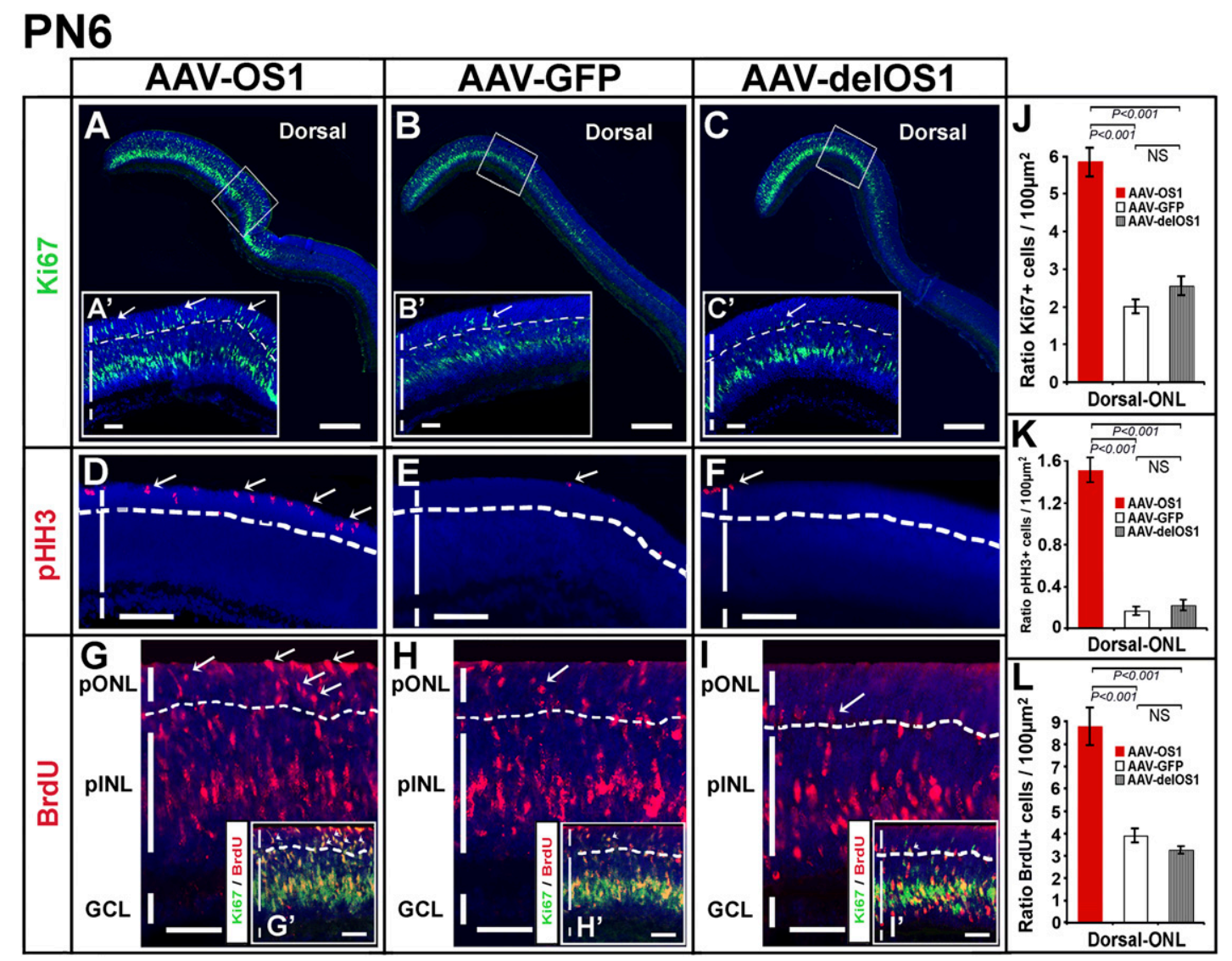

FIGURE 3. Vax2os1 overexpression in the retinal postnatal stages affects the correct proliferation of retinal progenitor cells. AAVs overexpressing Vax2os1 and the two control constructs were injected into the dorsal retinal areas of PN1 mice. (A-C) Ki67 fluorescent immunostaining (green signal) observed in the PN6 dorsal retina areas. $\left(A^{\prime}-C^{\prime}\right)$ Higher magnifications of the areas boxed in panels $A-C$. (Arrows) Ki67-positive cells in the prospective outer nuclear layer (pONL) of the AAV-OS1-injected retinas and the control construct-injected retinal areas. $(D-F) \mathrm{pHH}$ fluorescent immunostaining (in red) on the PN6 dorsal retina areas. (Arrows) pHH3-positive cells in the pONL of AAV-OS1-injected retinas and the control-injected retinal areas. ( $G-I)$ BrdU fluorescent detection in the PN6 dorsal retina areas. The BrdU was administered 24 h before killing the animals. There is an increase of BrdU-positive cells in the pONL of the AAV-OS1-injected retinas compared with the control-injected retinal areas (arrows). $\left(G^{\prime}-I^{\prime}\right)$ Lower magnifications of panels $G-H$ showing the results of coimmunostaining for BrdU and Ki67. The retinal cells positive to both the markers (in yellow) are present in the pINL and pONL in both the AAV-OS1- and control-injected retinas. However, there is an evident increase in the number of the BrdU/Ki67-positive cells in the pONL of the AAV-OS1-injected retinas compared with the controlinjected retinal areas (arrowheads). Note that the lower limit of the pONL is indicated with a dotted line. $(J-L)$ Counts of the Ki67 $(J)$, pHH3 $(K)$, and $\mathrm{BrdU}(L)$ positive cells in the dorsal ONL of the injected retinas at PN6. Areas of $30 \mu \mathrm{m} \times 20 \mu \mathrm{m}$ were used for manual counts. For each animal, multiple retinal areas were analyzed. (pINL) Prospective inner nuclear layer; (GCL) ganglion cell layer. Magnifying bars, $200 \mu \mathrm{m}(A-C)$; $40 \mu \mathrm{m}\left(A^{\prime}-C^{\prime}, G-I^{\prime}\right) ; 100 \mu \mathrm{m}(D-F)$. $(J-L)$ Values are means \pm SEM $(n=4)$ and $P$-values derived from likelihood ratio test for negative binomial.

areas (Supplemental Fig. 7E,F; data not shown). Interestingly, we also detected an increase in the number of cells that were positive to both $\mathrm{BrdU}$ and $\mathrm{Ki} 67$ staining $\left(\mathrm{BrdU}^{+} /\right.$ $\mathrm{Ki}^{+} 7^{+}$) in the ONL of the AAV-OS1-injected retinal areas

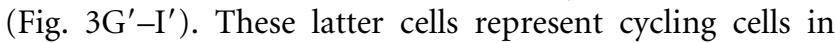
agreement with the result observed after Ki67 staining (Fig. $\left.3 \mathrm{~A}-\mathrm{C}^{\prime}\right)$. We did not observe any apparent abnormality in the morphology of AAV-OS1-injected retinal areas compared with the control-injected areas (Fig. 3A-I; data not shown). We could not assess the cellular identity of the increased cycling cells since in the prospective ONL of postnatal mouse retinas at PN6 different types of retinal progenitors are completing their last divisions (Baye and Link 2008; Yu et al. 2011).
Taken together, these data indicate that the misexpression of Vax2os1 in the dorsal retina determines a local perturbation in the cell cycle progression of the progenitor cells at the early stages of postnatal retinal development.

\section{Vax2os1 plays a role in the cell cycle progression and differentiation of photoreceptor progenitor cells}

At PN12, we still detected an increase of Ki67-positive cells in the dorsal ONL areas of the retinas injected with AAVOS1 (Fig. 4A, $\mathrm{A}^{\prime}, \mathrm{G}$ ), which indicated that these retinal progenitor cells had not yet exited the cell cycle. This is in strong contrast with the result observed in both the AAVGFP- and AAV-delOS1-injected eyes and in the ventral 
retinal areas (Fig. 4B, $\mathrm{B}^{\prime}$; data not shown), in which there were virtually no Ki67-positive cells, suggesting that all the retinal progenitors had exited the cell cycle by this stage (Barton and Levine 2008). This result indicated that the dorsal retinal progenitor cells that misexpress Vax2os 1 undergo a perturbation in their cell cycle progression. We hypothesized that this effect could also lead to an impairment of the differentiation processes. To verify this hypothesis, we stained the injected retinas with an antibody against acetylated $\alpha$-tubulin (acetyl- $\alpha \mathrm{Tub}$ ), which in the outermost region of the peripheral retina at this stage, is predominantly expressed in the connecting cilium of the nascent outer photoreceptor segments (nOS) (Arikawa and Williams 1993; Sung and Chuang 2010). This experiment revealed a decrease of acetyl- $\alpha$ Tub staining in the nOS of the dorsal AAV-OS1-injected retinas compared with similar areas of the control AAV-GFP-injected retinas. This result indicated a possible alteration in the process of ciliogenesis in the nascent photoreceptor axoneme of the AAV-OS1injected eyes (Fig. 4C-F,H; Supplemental Fig. 7G-J). Therefore, this latter finding shows that Vax2os1 overexpression affects mainly the progression of the photoreceptor progenitor cells toward their final differentiation.

To verify whether the Vax2os1-induced alteration in differentiation observed at PN12 could be linked to an increased cell death of the retinal cells that overexpress Vax2os1, we investigated the extent of apoptosis in the injected retinal areas by TUNEL staining. We found a signif- icant increase in the number of apoptotic cells in the photoreceptor layers of the OS1-OE-injected retinas compared with the GFP-injected retinal areas (Fig. 5A-E). This effect was specific to the site of injection since we did not observe any increase in cell death in the ventral retinal areas of the injected mice (data not shown). However, the increase in programmed cell death was restricted to a small number of cells within the injected retinal areas (Fig. 5AD). We did not observe any difference in the extent of apoptosis at earlier (PN6) or at later stages (data not shown) in the AAV-OS1-injected retinas. Altogether, the above results indicate that the overexpression of Vax2os1 alters the correct timing of photoreceptor cell proliferation, which leads to an increase in programmed cell death at selected stages of retinal development.

At PN30, the dorsal retinal areas of the AAV-OS1-injected animals showed a significant increase of BrdU-positive cells in the ONL compared with the control-injected retinas (Fig. 6; Supplemental Fig. 8C-E). This effect was particularly prominent not only in the most peripheral retinal regions, which are known to harbor proliferating cells until the late postnatal stages of retinal development (Fig. $6 \mathrm{~B}^{\prime}, \mathrm{C}^{\prime}$ ), but, even more remarkably, in the adjacent retinal regions, which we termed "near-peripheral" regions (Fig. 6A-C). No significant differences were observed in the number of BrdU-positive cells either in the INL, nor in more ventral areas of the AAV-OS1- compared with the control-injected retinas. These findings suggest that at the time of the BrdU

\section{PN12}

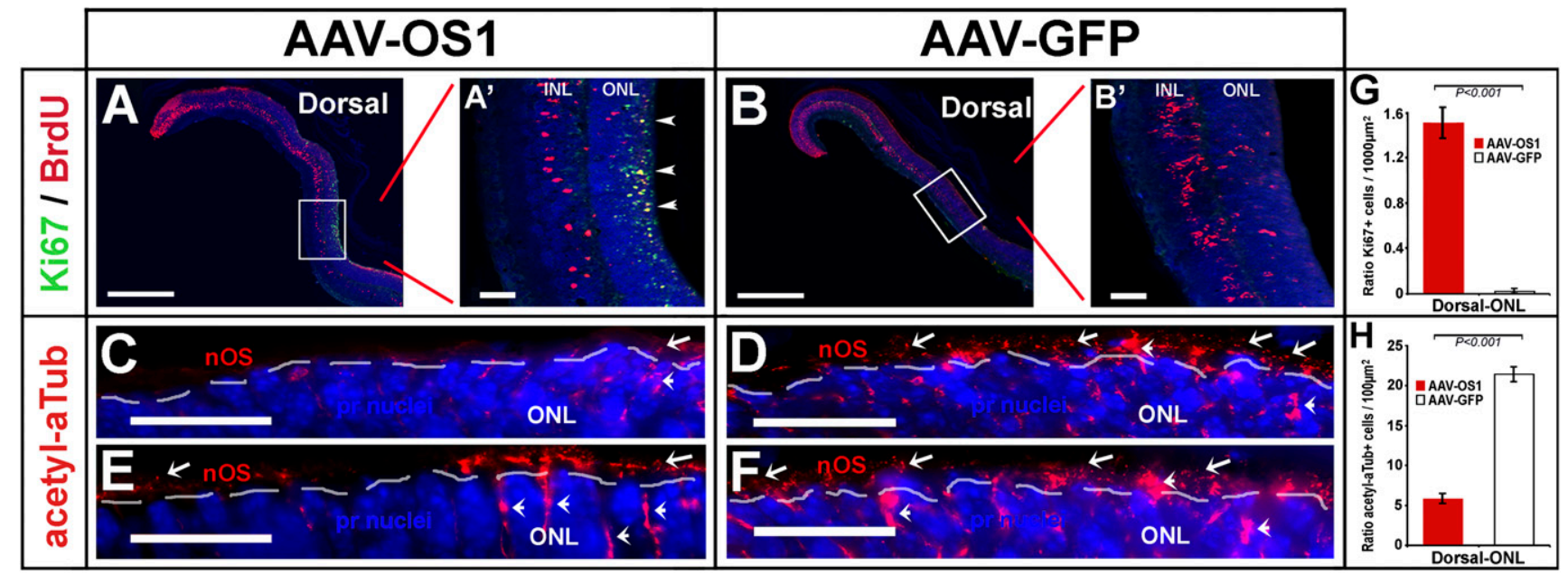

FIGURE 4. Alteration in the differentiation of photoreceptor cells following Vax2os1 overexpression. $(A, B)$ Fluorescence coimmunostaining for BrdU and Ki67 in the dorsal areas of PN1-injected retinas at PN12. $\left(A^{\prime}, B^{\prime}\right)$ Higher magnifications of the boxed areas in panels $A$ and $B$, respectively. There is an increase in the number of the cells positive to both BrdU and Ki67 (arrowheads in $A^{\prime}$ ) in the outer nuclear layer (ONL) of the AAV-OS1-injected retinas in comparison with the AAV-GFP-injected retinal areas. $(C-F)$ Fluorescence immunostaining for acetylated $\alpha$-tubulin (acetyl- $\alpha \mathrm{Tub}$ ) in the dorsal retinal areas of the injected mice at PN12. There is a decrease in the number of the acetyl- $\alpha$ Tub-positive photoreceptor cells (arrows) in the AAV-OS1-injected, as compared with the control-injected retinas. The dotted lines delimit the border between the nOS and the ONL. Note that acetyl- $\alpha$ Tub also stains the cytoplasm of Müller glial cells (arrowheads). (G,H) Counts of the Ki67-positive cells $(G)$ and acetyl-aTub-positive photoreceptor outer segments $(H)$ in the dorsal ONL of the injected retinas at PN12. Areas of $160 \mu \mathrm{m} \times 40 \mu \mathrm{m}(G)$ and $80 \mu \mathrm{m} \times 5 \mu \mathrm{m}(H)$ were used for manual counts. For each animal, multiple retinal areas were analyzed. Magnifying bars, $40 \mu \mathrm{m}\left(A^{\prime}, B^{\prime}\right) ; 20$ $\mu \mathrm{m}(C-F) .(G, H)$ Values are means $\pm \operatorname{SEM}(n=3)$ and $P$-values derived from likelihood ratio test for negative binomial. 


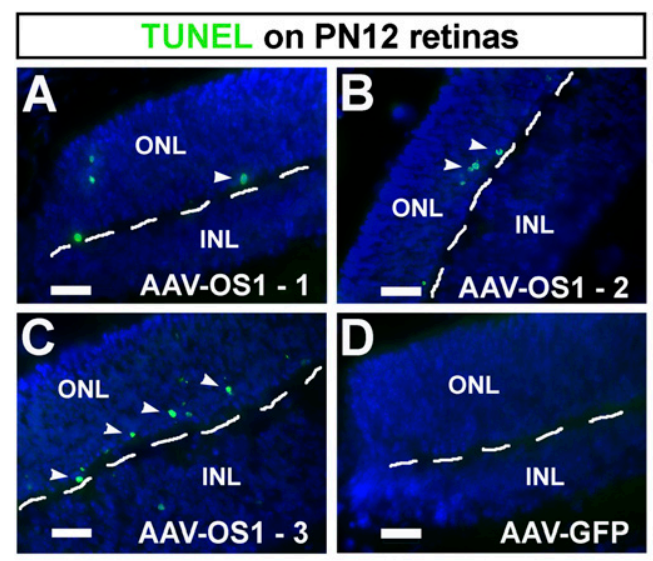

E

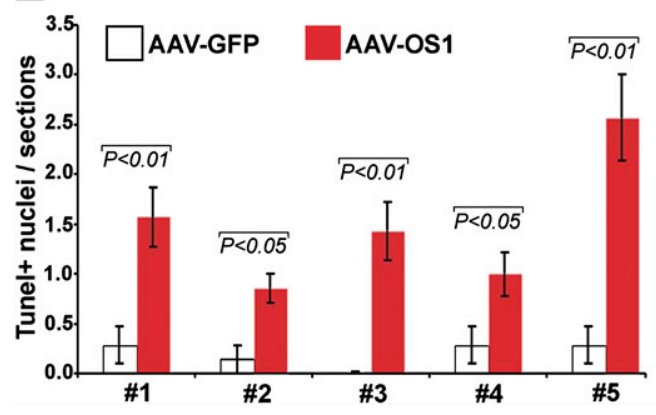

FIGURE 5. Increase of apoptosis at PN12 in the photoreceptor layer after Vax2os1-overexpression. $(A-D)$ Detection of programmed cell death by terminal deoxynucleotidyl transferase dUTP nick end labeling method (TUNEL, in green, arrowheads) in the dorsal retinas of the AAV-OS1- $(A-C)$ and AAV-GFP-injected $(D)$ mice. There is an increase in the number of the TUNEL-positive cells in the AAV-OS1versus control-injected retinas $(D)$. (E) Quantitative assessment/ section of the number of TUNEL-positive nuclei in the dorsal retinal regions analyzed. A significant increase of the TUNEL-positive cells was observed in the AAV-OS1-injected retinas over control-injected retinas in each of the five animals analyzed. Magnifying bars, $20 \mu \mathrm{m}$. (E) Results are means \pm SEM from seven technical replicates and $P$-values derived from a Student's $t$-test.

injections, namely, PN5 and PN6, a greater number of photoreceptor progenitors (mainly rod progenitors) were still proliferating in the AAV-OS1 peripheral retina than in the injected control retinas as previously described (Fig. 3).

We could not detect any Ki67-positive cells in the mature retinas (PN30) of either the AAV-OS1-injected or control AAV-GFP- and AAV-delOS1-injected retinas (Supplemental Fig. 8A,B). Moreover, we did not observe any difference in apoptosis between the AAV-OS1-injected and control-injected retinas (data not shown). Finally, neither morphological analysis by haematoxylin-eosin (data not shown) nor immunofluorescence stainings using rod (Rhodopsin), cone (mw- and sw-Opsin), and bipolar cell (Chx10) markers revealed a mislocalization of the photoreceptor nuclei or anomalies in retinal cell type identity between the injected areas of the AAV-OS1-injected and control-injected retina samples (Supplemental Fig. 8F-J; data not shown).
Taken together, all of the above data suggest that Vax2os1 misexpression at the early postnatal stages of retinal development causes a perturbation in the cell cycle progression of the retinal neuroblasts. This effect leads to a delay in the differentiation of the photoreceptor progenitor cells, which highlights a role of this lncRNA in controlling the proper maturation of photoreceptors.

\section{DISCUSSION}

LncRNAs are emerging as functional molecules that mediate important cellular processes (Nagano and Fraser 2011). However, there are only a few reports regarding the functional role of lncRNAs in retinal development (Young et al. 2005; Rapicavoli et al. 2010). In this study, we have gained an insight into the functional role of the retinal-specific IncRNA, Vax2os1, during retinal photoreceptor progenitor cell cycle progression and differentiation. This transcript displays a peculiar and dynamic expression profile in the mouse retina: It is abundantly expressed in the proliferating areas of the ventral embryonic retina, while it is considerably down-regulated in the early postnatal stages of retinal development. In the mature retina, Vax2os1 expression is up-regulated again and is restricted to the ONL of the ventral retina (Fig. 1), presumably more in rod than in cone cells, as suggested in a previous study (Corbo et al. 2007). Interestingly, we also provide the first evidence for the presence of a putative homolog of Vax2os1 in the human genome (Supplemental Fig. 3), which further highlights a functional role of this transcript across evolution. The above observations prompted us to test whether Vax2os1 could indeed be implicated in the regulation of photoreceptor cell proliferation and differentiation.

To gain an insight into the Vax2os1 function, we generated an in vivo mouse model of spatiotemporal misexpression of Vax2os1. We pursued this approach to (1) further assess the validity of the results obtained in vitro (Fig. 2; Supplemental Fig. 5) and (2) gain insight into the significance of the asymmetric distribution of this transcript along the dorsoventral axis of the retina. For the misexpression studies, we chose a stage (PN1) in which the majority of the retinal progenitor cells still have to undergo their final divisions (Barton and Levine 2008). At this stage, the mouse retina predominantly consists of photoreceptor progenitor cells, which, through asymmetric divisions, gradually generate post-mitotic photoreceptors and new cycling progenitors with a concomitant increasing time of cell cycle length (Alexiades and Cepko 1996; Li et al. 2000). We observed an impairment in the cell cycle progression of the retinal progenitor cells following Vax2os1 overexpression at different time points following injection at PN1 (Figs. 3-6). In particular, we showed that this effect is mainly evident in the photoreceptor progenitor cells as determined after BrdU pulses carried out at early stages and analyzed at PN30, i.e., when all of the retinal layers are 
PN30

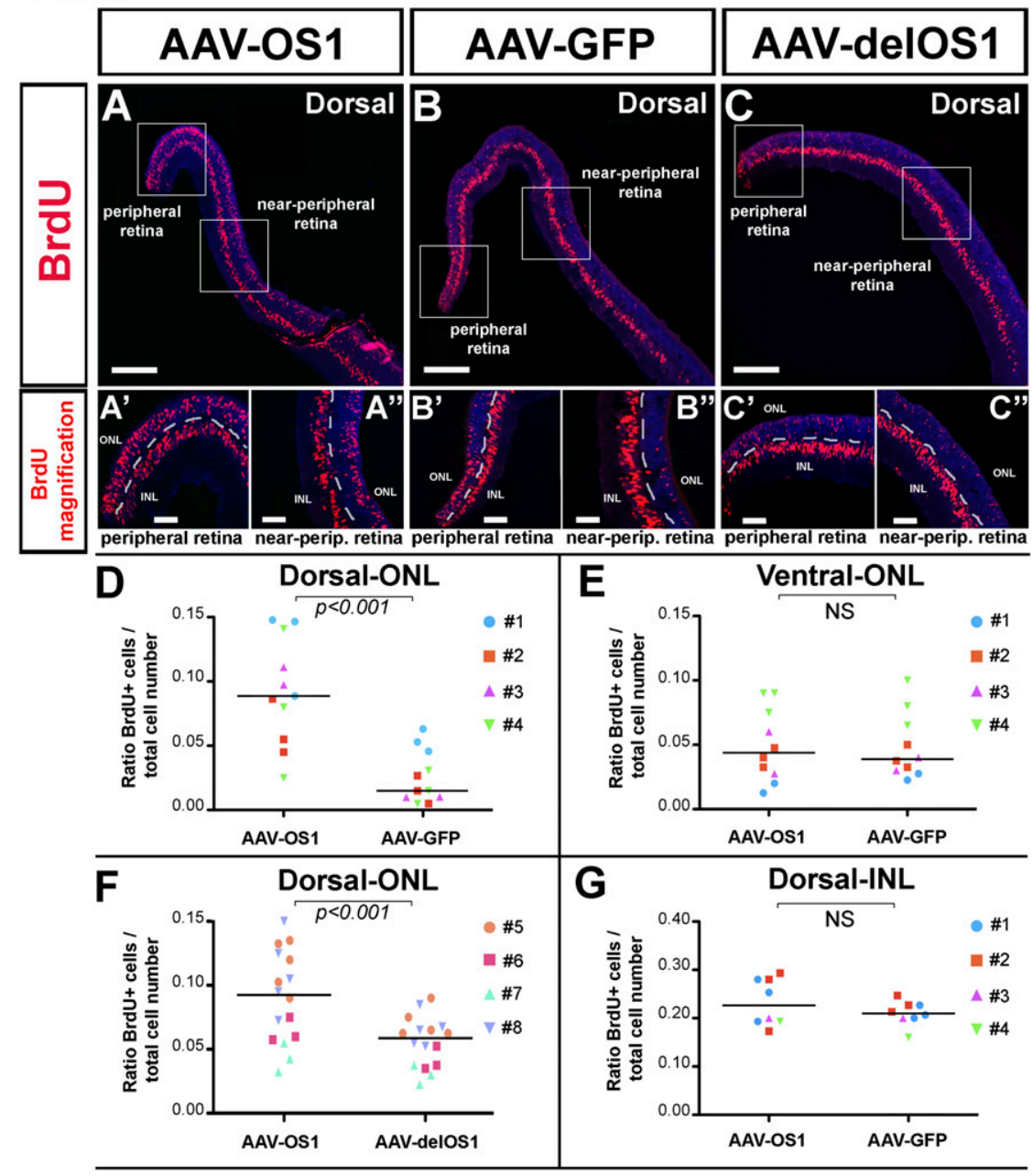

FIGURE 6. Vax2os1 action is restricted to the photoreceptor cells. $(A-C)$ The BrdU assay on PN30 dorsal retinal areas of mice injected at PN1. Two pulses of BrdU were performed, at PN5 and PN6, before sacrifice. $\left(A^{\prime}-C^{\prime}, A^{\prime \prime}-C^{\prime \prime}\right)$ Higher magnifications of, respectively, the peripheral and near-peripheral retinal areas boxed in panels $A-C$. $(D-G)$ Counts of BrdU-positive cells in the near-peripheral retinal areas of injected animals. In each panel, the identity of the animal analyzed is indicated. Areas of $80 \mu \mathrm{m} \times 40 \mu \mathrm{m}$ were used for manual BrdU counts. For each animal, multiple retinal areas were analyzed. ( $y$-axis) The total cell number value indicates the number of photoreceptor nuclei within the aforementioned areas. Magnifying bars, $200 \mu \mathrm{m}$ $(A-C) ; 40 \mu \mathrm{m}\left(A^{\prime}-C^{\prime \prime}\right)$. The horizontal line in each graphic represents the Grand Median as derived from the GraphPad Prism program. $(D-G)$ Data are means \pm SEM, $n=4$, and $P$-values derived from likelihood ratio test for negative binomial.

clearly defined and formed. However, we did not observe any obvious anomaly in the retinal morphology and in the final differentiation of photoreceptors in the mature retina of the Vax2os1-injected mice. Based on the above results, we conclude that the misexpression of Vax2os1 in the dorsal retina determines a cell cycle perturbation in the photoreceptor progenitors, which consists in a pronounced delay in cell cycle exit that, if prolonged during development, might induce some photoreceptor progenitors to undergo apoptosis (Fig. 5).

In mammals, the genesis of the mature photoreceptors occurs during a long temporal window either with a long cell proliferation phase (rods) or with a long post-mitotic cell maturation phase (cones). In particular, the rod photoreceptor progenitors are subject to a proliferation phase, which can last for several days in rodents, during which they gradually acquire a restriction of their differentiation competence and undergo progressive cell specification and commitment toward their fate (Young 1985; Hennig et al. 2008). During the latter phase, the photoreceptor progenitors must be competent to respond to inductive cues and cell fate determinants whose action can influence the rate of progress through the cell cycle of progenitor cells. We hypothesize that Vax2os1 may represent one of these factors and could prevent photoreceptor progenitor cells from undergoing a premature cell cycle exit at inappropriate times. The observed expression levels of Vax2os1 (high in the early phase of progenitor proliferation and low in the postnatal retina during the final divisions of progenitor cells) seem to support this hypothesis.

Another intriguing aspect of the Vax2os1 transcript is represented by its relationship with its neighboring gene Vax2. Expression studies performed by RNA ISH showed a similar expression pattern in the ventral retina for both transcripts, although they profoundly diverge in terms of retinal cell specificity, Vax2os1 being expressed in the photoreceptors and Vax2 in the retinal ganglion cells and interneurons (Barbieri et al. 2002; Mui et al. 2002). We previously reported that the inactivation of Vax2 by targeted recombination was accompanied by a concomitant down-regulation of Vax2os1 (Alfano et al. 2005). However, in the present study, we have not detected any significant variation in the expression levels of Vax2 after Vax2os1 overexpression either in vitro (661W cells) or in vivo, in the mouse retina (data not shown). This result suggests either that Vax2 controls the expression of Vax2os1 but not vice versa or that the down-regulation of Vax2os1 observed in the retina of $\operatorname{Vax} 2$ knockout mice is due to the loss of an expression control element located within the genomic fragment targeted by homologous recombination. In any case, this result indicates that the functional role played by Vax2os1 in photoreceptor cell differentiation is not mediated by changes in the expression levels of Vax2. 
Finally, our findings suggest a physiological role of Vax2os1 in ventral mouse retina development and maturation since Vax2os1 is also expressed in the adult photoreceptors. One of the main differentiation events that occur in an asymmetric fashion across the dorsal-ventral axis of the mammalian eye is represented by cone photoreceptor differentiation with an asymmetric distribution of the Opn1mw and Opn1sw genes along the dorsal-ventral axis of the retina (Cepko 1996; Hennig et al. 2008; Satoh et al. 2009). Interestingly, we recently found that $\operatorname{Vax2}$, the neighboring gene of Vax2os1, plays an important role in controlling cone opsin expression in the vertebrate eye by modulating the retinoic acid (RA) signaling (Alfano et al. 2011). On the other hand, the rod photoreceptor cells do not show any evident asymmetric expression pattern of their main proteins, e.g., Rhodopsin. Nevertheless there is some evidence of the asymmetric properties of the rod photoreceptors along the dorsal-ventral axis in the mammalian retina. For instance, it is known that rod photoreceptor cell death occurs preferentially in the dorsal retina of rats exposed to bright light (Gordon et al. 2002).

For all these reasons, it is tempting to speculate that Vax2os1 may play an important role in the appropriate specification of the ventral rod photoreceptors by acting as a cell cycle regulator of the retinal progenitors and in the maintenance of the adult photoreceptor cells. It will be of the utmost importance to verify the presence and the identity of possible molecular interactors of Vax2os1, either proteins, such as key components of the cell cycle, transcription factors, or histone-modifying proteins, as previously described for other lncRNAs (Feng et al. 2006; Khalil et al. 2009; Loewer et al. 2010), or other RNA molecules. Interestingly, a bioinformatic analysis of the conserved sequence domain, which we found to be essential for Vax2os1 function (Figs. 2, 3), provided preliminary evidence that it may represent a putative enhancer element, similar to what has been previously reported for other conserved sequences (Pennacchio et al. 2006). Moreover, a previous finding of a binding site for CRX validated by ChIP-seq, within the Vax2os1 conserved region, seems to further support this hypothesis (Corbo et al. 2010). CRX (Cone-Rod Homeobox) is a transcription factor known to play an important role in cone and rod maturation by regulating the expression of a number of photoreceptorspecific genes (Chen et al. 1997; Freund et al. 1997; Furukawa et al. 1997). Obviously, additional studies are required to prove this hypothesis and more in general clarify the mechanism of action of this transcript. Finally, in order to obtain a more complete picture of the physiological role of Vax2os1 in the retina, it will be essential to study the effects of its inactivation in vivo, possibly by means of targeted homologous recombination, or in vitro by antigene peptide nucleic acids (agPNAs) that target transcriptional start sites (Janowski et al. 2005) since RNA standard interference-based approaches failed to yield acceptable results.
The recognition that Vax2os1 is endowed with a functional role in the proper development of the mammalian retina further highlights the concept that the contribution of lncRNAs to the regulation of basic biological processes and gene regulatory networks must be taken into consideration. The availability of comprehensive transcriptome data sets generated from different tissues using next-generation sequencing procedures is expected to shed further light on the identification of additional functional lncRNAs and into the initial elucidation of their contribution to physiopathological processes.

\section{MATERIALS AND METHODS}

\section{Generation of the plasmid constructs}

The Vax2os1 full-length cDNA sequence was obtained from RNA samples of mouse adult retina retro-transcribed with the SuperScript III kit (Invitrogen) using a mixture of oligo(dT) and random primers. The PCR product for the Vax2os1 full-length sequence was obtained with EcoRV-tagged primers (Vax2os1RV.F, 5' -aaaagatatcGGACAGCCCCGTGGTACAGA-3'; Vax2os1RV.R, $5^{\prime}$-aaaagatatcTTTATTCAAAAAGAAGGATGCG-3') and digested with EcoRV (NEB) to obtain blunt ends. The digested PCR product was inserted in the pAAV2.1 CMV-BGH vector, CMV-citomegalovirus promoter, (Auricchio et al. 2001), provided by the TIGEM AAV Injection Core, previously linearized with PstI and BglII and blunt-ended with a T4 polymerase (Roche). The cassette comprising the CMV promoter, the Vax2os1 full-length, and the BGH poly(A) sequence was amplified with the XbaItagged primers (cOS1b-XbaI.F, 5'-gctctagagCTCCGCGTTACA TAACTTACGG-3'; cOS1b-XbaI.R, 5'-gctctagagCCCTTAACTC GAGTCCCCAGC-3'), then digested with XbaI and inserted in the pAAV2.1 CBA-eGFP-BGH, overexpressing the GFP protein under the chicken $\beta$-actin promoter (CBA), GFP-OE vector, (Allocca et al. 2007), previously linearized with NheI to obtain the final OS1-OE vector used for all the in vitro studies. To generate the control vectors overexpressing two mutagenized version of Vax2os1, the aforementioned plasmid was digested with ApaI (NEB) enzyme or double-digested with StuI/NheI (Roche) enzymes, then religated to obtain the final delOS1-OE and del2OS1OE vectors, respectively.

\section{Expression studies}

The embryonic and the adult murine eye tissues were obtained from C57BL/6 wild-type mice. For the expression studies in mouse and in human, total RNA was extracted and digested with DNase I using the RNeasy extraction kit (QIAGEN) according to the manufacturer's instructions. The cDNAs were generated by the Quantitect kit (QIAGEN) for the qRT-PCR analysis. As controls in the RT and qRT-PCR experiments, we used RT-menu samples, i.e., samples to which we did not add the reverse transcriptase enzyme in the cDNA preparation. The cDNAs for the directional qRT-PCR in human Y79 were generated by the SuperScript III kit (Invitrogen) using gene-specific primers (see Supplemental Table 1). The qRT-PCR reactions were performed with nested primers and the Roche Light Cycler 480 system (Roche). The PCR reaction per well was performed using cDNA 
(200-500 ng), $10 \mu \mathrm{L}$ of the SYBR Green Master Mix (Roche), and $400 \mathrm{nM}$ primer, in a total volume of $20 \mu \mathrm{L}$. The PCR conditions for all of the genes were as follows: preheating, $5 \mathrm{~min}$ at $95^{\circ} \mathrm{C}$; cycling, 40 cycles of $15 \mathrm{sec}$ at $95^{\circ} \mathrm{C}, 15 \mathrm{sec}$ at $60^{\circ} \mathrm{C}$, and $25 \mathrm{sec}$ at $72^{\circ} \mathrm{C}$. Quantification results were expressed in terms of cycle threshold (Ct). The $\mathrm{C}$ values were averaged for each triplicate. The Hprt gene was used as the endogenous control for the mouse experiments (reference marker). For the experiments in the human Y79 cells, HPRT1 was used as the endogenous control. Differences between the mean Ct values of the tested genes and those of the reference gene were calculated as $\Delta \mathrm{Ct}_{\text {gene }}=\mathrm{Ct}_{\text {gene }}-$ $\mathrm{Ct}_{\text {reference }}$ Relative expression was analyzed as $2^{-\Delta \mathrm{Ct}}$. Relative fold changes in expression levels were determined as $2^{-\Delta \Delta \mathrm{Ct}}$.

The sequences of the oligonucleotide primers are summarized in Supplemental Table 1.

RNA in situ experiments on whole embryos and eye sections were performed as described (Alfano et al. 2005) with digoxigeninlabeled antisense RNA probes. ISH probes for Vax2os1 and Vax2 were obtained by RT-PCR on the mouse adult retina RNA using the SuperScript III kit (Invitrogen) and then inserted in the Topo TA vector Dual Promoter (Invitrogen) for probe transcription with DIG-labeled nucleotides (Roche).

\section{Cell culture}

The $661 \mathrm{~W}$ photoreceptor cell line was a generous gift of M.R. AlUbaidi. $661 \mathrm{~W}$ cells (Al-Ubaidi et al. 1992) were grown at $37^{\circ} \mathrm{C}$ and $5 \% \mathrm{CO}_{2}$ in DMEM supplemented with $10 \% \mathrm{FBS}$, penicillin (100 $\mathrm{U} / \mathrm{mL})$, and streptomycin $(50 \mathrm{mg} / \mathrm{mL})$. The cells were cultured overnight and transfected with $0.4 \mathrm{mg}$ of DNA using PolyFect transfection reagent (QIAGEN) according to the manufacturer's instructions. The $661 \mathrm{~W}$ cells were cultured for $1 \mathrm{~d}$ after transfection and then treated with $4 \mathrm{mM} \mathrm{Na}$ butyrate, $50 \mathrm{mM}$ taurine, $50 \mathrm{ng} / \mathrm{mL}$ bFGF, and $27.32 \mathrm{mg} / \mathrm{mL}$ heparin. The Y79 cells (HTB18, ATCC) were maintained as stock cultures in RPMI-1640 medium (GIBCO) supplemented with penicillin, streptomycin, and $20 \%$ FBS. For the differentiation experiments, the cells were plated in a synthetic medium, which is serum-free MEM containing an N2 supplement (GIBCO) (MEM-N2). They were cultured in poly-L-ornithine/laminin-coated culture 100-mm dishes (Sigma-Aldrich) and maintained for $3 \mathrm{~d}$. Sodium butyrate $(\mathrm{NaBu})$ was dissolved in MEM at the final concentration of $1 \mathrm{mM}$.

\section{Immunofluorescence and FACS}

For the in vitro immunofluorescence experiments, the cells were fixed with $4 \%$ paraformaldehyde for $10 \mathrm{~min}$, permeabilized with $0.3 \%$ Triton X-100 in PBS for 5 min, and blocked with $5 \%$ goat serum and $4 \%$ BSA in PBS for $30 \mathrm{~min}$. The primary antibody mixtures were applied overnight at $4^{\circ} \mathrm{C}$.

For the immunofluorescence analysis on the eye sections, mouse eyes were fixed overnight in $4 \%$ paraformaldehyde in PBS at $4^{\circ} \mathrm{C}$, incubated for $1 \mathrm{~h}$ in $20 \%$ sucrose/PBS, and incubated overnight in $30 \%$ sucrose/PBS at $4^{\circ} \mathrm{C}$. The eyes were orientated and flash-frozen in O.C.T (Kaltek) using liquid nitrogen steam. The cryopreserved sections were permeabilized with $0.5 \%$ Triton X-100 in PBS and blocked with $10 \%$ goat serum in PBS/0.2\% Triton X-100 for 30 min. For the BrdU and Ki67 staining, sections were boiled, after fixation, in $10 \mathrm{mM}$ sodium citrate buffer ( $\mathrm{pH}$ 6.0) for $3 \mathrm{~min}$. An additional denaturation step with $2 \mathrm{~N}$ chloridric acid for $30 \mathrm{~min}$, and neutralization in PBS was performed for the BrdU detection.
The primary antibodies used are a monoclonal anti-BrdU (mouse, clone BU-33; Sigma-Aldrich) 1:300 and anti-phosphoHistone-H3 (Ser10, rabbit; Millipore) 1:200 for both the in vitro and in vivo studies; anti-Ki67 (mouse, clone B56; BD Pharmingen) 1:100 for the in vitro studies and monoclonal anti-Ki67 (rat, clone TEC-3; Dako) for the in vivo studies; monoclonal anti-Neuronal class III $\beta$-tubulin (mouse, clone Tuj-1; Covance); anti-Rhodopsin (mouse, clone RET-P1; Sigma-Aldrich) 1:1000; monoclonal antiacetylated- $\alpha$-tubulin (mouse, clone 6-11B-1; Sigma-Aldrich) 1:500, anti-Opsin, Blue (sw) and Green/Red (mw) (rabbit; Millipore) 1:200; anti-Chx10 (goat, clone C-17; Santa Cruz Biotechnology) 1:100. The ABC kit (Vector Laboratories) and TSA-plus fluorescein (Perkin Elmer) were used according to the manufacturer's instructions to amplify the signal in Ki67 staining on eye sections. Slides were incubated with the Alexa Fluor secondary antibodies (Invitrogen) 1:1000. Cells and sections were counterstained with 4.6-diamidino-2-phenylindol (DAPI; Vector Laboratories). Slides were photographed using both Leica DM5000 and Zeiss Axioplan microscopes.

The flow cytometric analysis of GFP-positive cells was performed on a FACS ARIA Flow cytometer (BD Biosciences), and the results were analyzed using DIVA software. Pooled cells from five biological replicates were sorted and permeabilized with icecold $70 \%$ ethanol for $1 \mathrm{~h}$ and then digested with $0.05 \mathrm{mg} / \mathrm{mL}$ RNase A (Roche) for $30 \mathrm{~min}$ at $4^{\circ} \mathrm{C}$. The cells were then pelleted and resuspended in $2 \mathrm{~mL}$ with $0.005 \mathrm{mg} / \mathrm{mL}$ propidium iodide (P-4170; Sigma-Aldrich) for $1 \mathrm{~h}$ at $4^{\circ} \mathrm{C}$ before being analyzed (FCS-A vs. FCS-W plot).

Unless described elsewhere, each the in vitro experiment was performed using three biological replicates.

\section{TUNEL assay}

Apoptotic nuclei were detected by the TdT-mediated dUTP terminal nick-end labeling kit according to the manufacturer's instructions (TUNEL; Roche).

\section{$A A V$ virus and BrdU administration}

All the procedures on animals were performed under a protocol approved by the Hospital Cardarelli Ethics Committee, Naples, Italy, and by the Italian Ministry of Health. Wild-type C57BL/6 mice (Charles River) were used. Recombinant AAV2/8 viruses were produced by the TIGEM AAV Injection Core according to protocols described elsewhere (Hildinger et al. 2001). As DNA templates, the same plasmids used for the in vitro experiments were used for AAV production. For each viral preparation, physical titers (genome copies per milliliter, $\mathrm{GC} / \mathrm{mL}$ ) were determined by PCR quantification using TaqMan (Gao et al. 2000). Adult animals were killed by neck dislocation. Postnatal mice at postnatal day 1 (PN1-2) were anesthetized by hypothermia for 2 min at $4^{\circ} \mathrm{C}$ (Venables et al. 2002) and injected subretinally in the dorsal retinal areas with $1 \mu \mathrm{L}$ of AAV vectors corresponding to $1 \times 10^{9}$ genome copies (GC). In particular, the right eye was always injected with AAVs overexpressing Vax2os1 and the left eye with one of the two control AAV vectors. The same individual performed all the surgical procedures to minimize variability in injection technique.

The BrdU was administrated intraperitoneally at the concentration of $0.05 \mathrm{mg} / \mathrm{g}$ to $\mathrm{PN} 5$ mice and sacrificed $24 \mathrm{~h}$ after in case 
of short-pulse studies or another administration of BrdU was performed the day after in case of long-pulse studies.

For the in vivo experiments, at least $n=4$ animals were used for each experiment.

\section{Statistics}

Data are presented as means \pm SE or \pm SEM where indicated. Two-tailed Student's $t$-tests, likelihood ratio tests for negative binomial (Maxwell and Delaney 2004), and Pearson's $\chi^{2}$ test were used to determine statistical significance where indicated. $P \leq$ 0.05 was considered significant.

\section{SUPPLEMENTAL MATERIAL}

Supplemental material is available for this article.

\section{ACKNOWLEDGMENTS}

We are grateful to Dr. Muayyad R. Al-Ubaidi (University of Oklahoma) for providing us with the $661 \mathrm{~W}$ cell line. We thank Professor Veronica van Heyningen for helpful discussion and for her continuous support; and Dr. I. Conte and Dr. G. Diez-Roux for the critical reading of the manuscript. We also thank the TIGEM Bioinformatic Core for assistance in statistical and bioinformatic analyses; E. Nusco for husbandry of the animals used in this study; and Dr. V. Bouchè, Dr. R.I. Cervigni, Dr. A. D’Angelo, Dr. D.L. Medina, and Dr. P. Colella for experimental support. This work was supported by the Italian Telethon Foundation and the Italian Ministry of Health.

Received July 21, 2011; accepted October 21, 2011.

\section{REFERENCES}

Alexiades MR, Cepko C. 1996. Quantitative analysis of proliferation and cell cycle length during development of the rat retina. Dev Dyn 205: 293-307.

Alfano G, Vitiello C, Caccioppoli C, Caramico T, Carola A, Szego MJ, McInnes RR, Auricchio A, Banfi S. 2005. Natural antisense transcripts associated with genes involved in eye development. Hum Mol Genet 14: 913-923.

Alfano G, Conte I, Caramico T, Avellino R, Arnò B, Pizzo MT, Tanimoto N, Beck SC, Huber G, Dollé P, et al. 2011. Vax2 regulates retinoic acid distribution and cone opsin expression in the vertebrate eye. Development 138: 261-271.

Allocca M, Mussolino C, Garcia-Hoyos M, Sanges D, Iodice C, Petrillo M, Vandenberghe LH, Wilson JM, Marigo V, Surace EM, et al. 2007. Novel adeno-associated virus serotypes efficiently transduce murine photoreceptors. J Virol 81: 11372-11380.

Al-Ubaidi MR, Font RL, Quiambao AB, Keener MJ, Liou GI, Overbeek PA, Baehr W. 1992. Bilateral retinal and brain tumors in transgenic mice expressing simian virus 40 large $\mathrm{T}$ antigen under control of the human interphotoreceptor retinoid-binding protein promoter. J Cell Biol 119: 1681-1687.

Amaral PP, Mattick JS. 2008. Noncoding RNA in development. Mamm Genome 19: 454-492.

Arikawa K, Williams DS. 1993. Acetylated $\alpha$-tubulin in the connecting cilium of developing rat photoreceptors. Invest Ophthalmol Vis Sci 34: $2145-2149$.

Auricchio A, Kobinger G, Anand V, Hildinger M, O'Connor E, Maguire AM, Wilson JM, Bennett J. 2001. Exchange of surface proteins impacts on viral vector cellular specificity and trans- duction characteristics: The retina as a model. Hum Mol Genet 10: 3075-3081.

Barbieri AM, Lupo G, Bulfone A, Andreazzoli M, Mariani M, Fougerousse F, Consalez GG, Borsani G, Beckmann JS, Barsacchi $\mathrm{G}$, et al. 1999. A homeobox gene, vax2, controls the patterning of the eye dorsoventral axis. Proc Natl Acad Sci 96: 10729-10734.

Barbieri AM, Broccoli V, Bovolenta P, Alfano G, Marchitiello A, Mocchetti C, Crippa L, Bulfone A, Marigo V, Ballabio A, et al. 2002. Vax2 inactivation in mouse determines alteration of the eye dorsal-ventral axis, misrouting of the optic fibres and eye coloboma. Development 129: 805-813.

Barton KM, Levine EM. 2008. Expression patterns and cell cycle profiles of PCNA, MCM6, cyclin D1, cyclin A2, cyclin B1, and phosphorylated histone $\mathrm{H} 3$ in the developing mouse retina. Dev Dyn 237: 672-682.

Baye LM, Link BA. 2008. Nuclear migration during retinal development. Brain Res 1192: 29-36.

Birney E, Stamatoyannopoulos JA, Dutta A, Guigo R, Gingeras TR, Margulies EH, Weng Z, Snyder M, Dermitzakis ET, Thurman RE, et al. 2007. Identification and analysis of functional elements in $1 \%$ of the human genome by the ENCODE pilot project. Nature 447: 799-816.

Boatright JH, Stodulkova E, Do VT, Padove SA, Nguyen HT, Borst DE, Nickerson JM. 2002. The effect of retinoids and butyrate on the expression of CRX and IRBP in retinoblastoma cells. Vision Res 42: 933-938.

Carninci P, Yasuda J, Hayashizaki Y. 2008. Multifaceted mammalian transcriptome. Curr Opin Cell Biol 20: 274-280.

Carthew RW, Sontheimer EJ. 2009. Origins and mechanisms of miRNAs and siRNAs. Cell 136: 642-655.

Cepko CL. 1996. The patterning and onset of opsin expression in vertebrate retinae. Curr Opin Neurobiol 6: 542-546.

Chen S, Wang QL, Nie Z, Sun H, Lennon G, Copeland NG, Gilbert DJ, Jenkins NA, Zack DJ. 1997. Crx, a novel Otx-like pairedhomeodomain protein, binds to and transactivates photoreceptor cell-specific genes. Neuron 19: 1017-1030.

Colella P, Auricchio A. 2010. AAV-mediated gene supply for treatment of degenerative and neovascular retinal diseases. Curr Gene Ther 10: 371-380.

Comitato A, Spampanato C, Chakarova C, Sanges D, Bhattacharya SS, Marigo V. 2007. Mutations in splicing factor PRPF3, causing retinal degeneration, form detrimental aggregates in photoreceptor cells. Hum Mol Genet 16: 1699-1707.

Corbo JC, Myers CA, Lawrence KA, Jadhav AP, Cepko CL. 2007. A typology of photoreceptor gene expression patterns in the mouse. Proc Natl Acad Sci 104: 12069-12074.

Corbo JC, Lawrence KA, Karlstetter M, Myers CA, Abdelaziz M, Dirkes W, Weigelt K, Seifert M, Benes V, Fritsche LG, et al. 2010. CRX ChIP-seq reveals the cis-regulatory architecture of mouse photoreceptors. Genome Res 20: 1512-1525.

Czech B, Malone CD, Zhou R, Stark A, Schlingeheyde C, Dus M, Perrimon N, Kellis M, Wohlschlegel JA, Sachidanandam R, et al. 2008. An endogenous small interfering RNA pathway in Drosophila. Nature 453: 798-802.

Dinger ME, Amaral PP, Mercer TR, Pang KC, Bruce SJ, Gardiner BB, Askarian-Amiri ME, Ru K, Solda G, Simons C, et al. 2008. Long noncoding RNAs in mouse embryonic stem cell pluripotency and differentiation. Genome Res 18: 1433-1445.

Ebisuya M, Yamamoto T, Nakajima M, Nishida E. 2008. Ripples from neighbouring transcription. Nat Cell Biol 10: 1106-1113.

Feng J, Bi C, Clark BS, Mady R, Shah P, Kohtz JD. 2006. The Evf-2 noncoding RNA is transcribed from the Dlx-5/6 ultraconserved region and functions as a Dlx-2 transcriptional coactivator. Genes Dev 20: $1470-1484$.

Freund CL, Gregory-Evans CY, Furukawa T, Papaioannou M, Looser J, Ploder L, Bellingham J, Ng D, Herbrick JA, Duncan A, et al. 1997. Cone-rod dystrophy due to mutations in a novel photoreceptor-specific homeobox gene (CRX) essential for maintenance of the photoreceptor. Cell 91: 543-553. 
Furukawa T, Morrow EM, Cepko CL. 1997. Crx, a novel otx-like homeobox gene, shows photoreceptor-specific expression and regulates photoreceptor differentiation. Cell 91: 531-541.

Gao G, Qu G, Burnham MS, Huang J, Chirmule N, Joshi B, Yu QC, Marsh JA, Conceicao CM, Wilson JM. 2000. Purification of recombinant adeno-associated virus vectors by column chromatography and its performance in vivo. Hum Gene Ther 11: 20792091.

Gordon WC, Casey DM, Lukiw WJ, Bazan NG. 2002. DNA damage and repair in light-induced photoreceptor degeneration. Invest Ophthalmol Vis Sci 43: 3511-3521.

Gupta RA, Shah N, Wang KC, Kim J, Horlings HM, Wong DJ, Tsai MC, Hung T, Argani P, Rinn JL, et al. 2010. Long non-coding RNA HOTAIR reprograms chromatin state to promote cancer metastasis. Nature 464: 1071-1076.

Hennig AK, Peng GH, Chen S. 2008. Regulation of photoreceptor gene expression by Crx-associated transcription factor network. Brain Res 1192: 114-133.

Hildinger M, Auricchio A, Gao G, Wang L, Chirmule N, Wilson JM. 2001. Hybrid vectors based on adeno-associated virus serotypes 2 and 5 for muscle-directed gene transfer. J Virol 75: 6199-6203.

Huarte M, Rinn JL. 2010. Large non-coding RNAs: Missing links in cancer? Hum Mol Genet 19: R152-R161.

Huarte M, Guttman M, Feldser D, Garber M, Koziol MJ, KenzelmannBroz D, Khalil AM, Zuk O, Amit I, Rabani M, et al. 2010. A large intergenic non-coding RNA induced by p53 mediates global gene repression in the p53 response. Cell 142: 409-419.

Janowski BA, Huffman KE, Schwartz JC, Ram R, Hardy D, Shames DS, Minna JD, Corey DR. 2005. Inhibiting gene expression at transcription start sites in chromosomal DNA with antigene RNAs. Nat Chem Biol 1: 216-222.

Kapranov P, Cheng J, Dike S, Nix DA, Duttagupta R, Willingham AT, Stadler PF, Hertel J, Hackermuller J, Hofacker IL, et al. 2007. RNA maps reveal new RNA classes and a possible function for pervasive transcription. Science 316: 1484-1488.

Khalil AM, Guttman M, Huarte M, Garber M, Raj A, Rivea Morales D, Thomas K, Presser A, Bernstein BE, van Oudenaarden A, et al. 2009. Many human large intergenic noncoding RNAs associate with chromatin-modifying complexes and affect gene expression. Proc Natl Acad Sci 106: 11667-11672.

Lapidot M, Pilpel Y. 2006. Genome-wide natural antisense transcription: Coupling its regulation to its different regulatory mechanisms. EMBO Rep 7: 1216-1222.

Li Z, Hu M, Ochocinska MJ, Joseph NM, Easter SS Jr. 2000. Modulation of cell proliferation in the embryonic retina of zebrafish (Danio rerio). Dev Dyn 219: 391-401.

Loewer S, Cabili MN, Guttman M, Loh YH, Thomas K, Park IH, Garber M, Curran M, Onder T, Agarwal S, et al. 2010. Large intergenic non-coding RNA-RoR modulates reprogramming of human induced pluripotent stem cells. Nat Genet 42: 1113-1117.

Mattick JS. 2009. The genetic signatures of noncoding RNAs. PLoS Genet 5: e1000459. doi: 10.1371/journal.pgen.1000459.

Maxwell SE, Delaney HD. 2004. Designing experiments and analyzing data: A model comparison perspective. Lawrence Erlbaum Associates, Hillsdale, NJ.

Mercer TR, Dinger ME, Sunkin SM, Mehler MF, Mattick JS. 2008. Specific expression of long noncoding RNAs in the mouse brain. Proc Natl Acad Sci 105: 716-721.

Mercer TR, Dinger ME, Mattick JS. 2009. Long non-coding RNAs: Insights into functions. Nature Rev 10: 155-159.

Mui SH, Hindges R, O'Leary DD, Lemke G, Bertuzzi S. 2002. The homeodomain protein Vax2 patterns the dorsoventral and nasotemporal axes of the eye. Development 129: 797-804.

Nagano T, Fraser P. 2011. No-nonsense functions for long noncoding RNAs. Cell 145: 178-181.

Ohsaki K, Morimitsu T, Ishida Y, Kominami R, Takahashi N. 1999. Expression of the Vax family homeobox genes suggests multiple roles in eye development. Genes Cells 4: 267-276.
Ong CT, Corces VG. 2011. Enhancer function: New insights into the regulation of tissue-specific gene expression. Nature Rev 12: 283 293.

Pang KC, Frith MC, Mattick JS. 2006. Rapid evolution of noncoding RNAs: Lack of conservation does not mean lack of function. Trends Genet 22: 1-5.

Pauli A, Rinn JL, Schier AF. 2011. Non-coding RNAs as regulators of embryogenesis. Nature Rev 12: 136-149.

Peng GH, Chen S. 2007. Crx activates opsin transcription by recruiting HAT-containing co-activators and promoting histone acetylation. Hum Mol Genet 16: 2433-2452.

Pennacchio LA, Ahituv N, Moses AM, Prabhakar S, Nobrega MA, Shoukry M, Minovitsky S, Dubchak I, Holt A, Lewis KD, et al. 2006. In vivo enhancer analysis of human conserved non-coding sequences. Nature 444: 499-502.

Ponjavic J, Ponting CP. 2007. The long and the short of RNA maps. Bioessays 29: 1077-1080.

Ponting CP, Oliver PL, Reik W. 2009. Evolution and functions of long noncoding RNAs. Cell 136: 629-641.

Rapicavoli NA, Blackshaw S. 2009. New meaning in the message: Noncoding RNAs and their role in retinal development. Dev Dyn 238: 2103-2114.

Rapicavoli NA, Poth EM, Blackshaw S. 2010. The long noncoding RNA RNCR2 directs mouse retinal cell specification. BMC Dev Biol 10: 49. doi: 10.1186/1471-213X-10-49.

Ravasi T, Suzuki H, Pang KC, Katayama S, Furuno M, Okunishi R, Fukuda S, Ru K, Frith MC, Gongora MM, et al. 2006. Experimental validation of the regulated expression of large numbers of noncoding RNAs from the mouse genome. Genome Res 16: 11-19.

Reid TW, Albert DM, Rabson AS, Russell P, Craft J, Chu EW, Tralka TS, Wilcox JL. 1974. Characteristics of an established cell line of retinoblastoma. J Natl Cancer Inst 53: 347-360.

Rinn JL, Kertesz M, Wang JK, Squazzo SL, Xu X, Brugmann SA, Goodnough LH, Helms JA, Farnham PJ, Segal E, et al. 2007. Functional demarcation of active and silent chromatin domains in human HOX loci by noncoding RNAs. Cell 129: 1311-1323.

Satoh S, Tang K, Iida A, Inoue M, Kodama T, Tsai SY, Tsai MJ, Furuta Y, Watanabe S. 2009. The spatial patterning of mouse cone opsin expression is regulated by bone morphogenetic protein signaling through downstream effector COUP-TF nuclear receptors. J Neurosci 29: 12401-12411.

Sung CH, Chuang JZ. 2010. The cell biology of vision. J Cell Biol 190: 953-963.

Surace EM, Auricchio A, Reich SJ, Rex T, Glover E, Pineles S, Tang W, O'Connor E, Lyubarsky A, Savchenko A, et al. 2003. Delivery of adeno-associated virus vectors to the fetal retina: Impact of viral capsid proteins on retinal neuronal progenitor transduction. J Virol 77: 7957-7963.

Tsai MC, Manor O, Wan Y, Mosammaparast N, Wang JK, Lan F, Shi Y, Segal E, Chang HY. 2010. Long noncoding RNA as modular scaffold of histone modification complexes. Science 329: 689-693.

Venables WN, Ripley BD, Venables WN. 2002. Modern applied statistics with $S$. Springer, New York.

Wang KC, Yang YW, Liu B, Sanyal A, Corces-Zimmerman R, Chen Y, Lajoie BR, Protacio A, Flynn RA, Gupta RA, et al. 2011. A long noncoding RNA maintains active chromatin to coordinate homeotic gene expression. Nature 472: 120-124.

Werner A, Carlile M, Swan D. 2009. What do natural antisense transcripts regulate? RNA Biol 6: 43-48.

Young RW. 1985. Cell proliferation during postnatal development of the retina in the mouse. Brain Res 353: 229-239.

Young TL, Matsuda T, Cepko CL. 2005. The noncoding RNA Taurine Upregulated Gene 1 is required for differentiation of the murine retina. Curr Biol 15: 501-512.

Yu J, Lei K, Zhou M, Craft CM, Xu G, Xu T, Zhuang Y, Xu R, Han M. 2011. KASH protein Syne-2/Nesprin-2 and SUN proteins SUN1/2 mediate nuclear migration during mammalian retinal development. Hum Mol Genet 20: 1061-1073. 

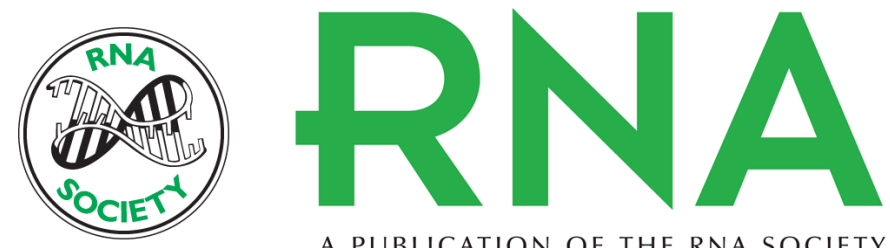

A PUBLICATION OF THE RNA SOCIETY

\section{The long noncoding RNA Vax2os1 controls the cell cycle progression of photoreceptor progenitors in the mouse retina}

Nicola Meola, Mariateresa Pizzo, Giovanna Alfano, et al.

RNA 2012 18: 111-123 originally published online November 29, 2011

Access the most recent version at doi:10.1261/rna.029454.111

\section{Supplemental http://rnajournal.cshlp.org/content/suppl/2011/11/17/rna.029454.111.DC1 \\ Material}

References This article cites 68 articles, 21 of which can be accessed free at: http://rnajournal.cshlp.org/content/18/1/111.full.html\#ref-list-1

Open Access Freely available online through the RNA Open Access option.

License Freely available online through the RNA Open Access option.

Email Alerting Receive free email alerts when new articles cite this article - sign up in the box at the Service top right corner of the article or click here.

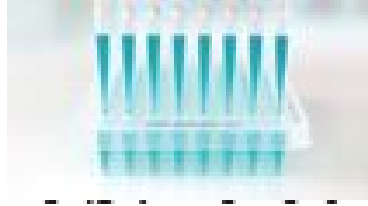

Providing Precise Solutions for your research.

To subscribe to RNA go to:

http://rnajournal.cshlp.org/subscriptions 